\title{
Binuclear Metal Complexes of a Doubly Bridged Cyclopentadienyl Ligand'
}

\author{
Ulrich Siemeling, " Peter Jutzi, Beate Neumann, ${ }^{\dagger}$ and Hans-Georg Stammler ${ }^{\dagger}$ \\ Fakultät für Chemie der Universität, Universitätsstrasse, W-4800 Bielefeld 1, Federal Republic of Germany \\ Michael B. Hursthouse ${ }^{\dagger}$ \\ Chemistry Department, Queen Mary and Westfield College, London E1 4NS, Untted Kingdom
}

Recelved July 19, 1991

\begin{abstract}
Binuclear metal complexes derived from the doubly bridged cyclopentadiene system 2,2,8,8-tetramethyl-2,8-disilatricyclo[7.3.0.0,7] dodeca-3,5,9,11-tetraene $\left(\mathrm{LH}_{2}\right)$ are examined. This compound is deprotonated with 2 equiv of 1-butyllithium to form the dilithio salt $\mathrm{LLi}_{2}(2)$. Reaction of 2 with trimethyltin chloride yields $\left(\mathrm{Me}_{3} \mathrm{Sn}\right)_{2} \mathrm{~L}$ (3). The analogous reaction with $\mathrm{Cp} * \mathrm{RuCl}\left(\mathrm{Cp} *=\mathrm{C}_{5} \mathrm{Me}_{5}\right)$ gives the binuclear ruthenocene (Cp*Ru) $)_{2} \mathrm{~L}(4)$. By cocomplexation of 2 and $\mathrm{Cp} * \mathrm{Li}$ with iron(II) chloride, the binuclear ferrocene $(\mathrm{Cp} * \mathrm{Fe})_{2} \mathrm{~L}(5)$ is obtained. Reaction of $\mathrm{LH}_{2}$ with octacarbonyldicobalt leads to the formation of $\left[(\mathrm{CO})_{2} \mathrm{Co}\right]_{2} \mathrm{~L}$ (6). The analogous reaction with pentacarbonyliron yields a mixture of products, from which $\left[(\mathrm{CO})_{2} \mathrm{Fe}\right]_{2} \mathrm{~L}$ $(\mathrm{Fe}-\mathrm{Fe})(7)$ is isolated. The stereochemistry of complexes 3-7 is investigated by IR and NMR spectroscopy. Single-crystal X-ray structure determinations are performed for 5 and $\mathbf{6}$. The structure investigations on 5 show a trans arrangement of the two $\mathrm{Cp} * \mathrm{Fe}$ units. The ligand $\mathrm{L}$ is not planar. The unit cell contains two independent molecules, whose bonding parameters are essentially identical (crystal system triclinic; space group $P \overline{1} ; a=8.7443(13), \AA, b=18.561(3) \AA, c=20.576(4) \AA ; \alpha=89.340(13)^{\circ}, \beta=89.160(13)^{\circ}$, $\left.\gamma=78.300(12)^{\circ} ; Z=4\right)$. The structure investigations on the cis isomer of 6 also show a nonplanar ligand $\mathrm{L}$ (crystal system monoclinic; space group $\mathrm{P} 2 / \mathrm{n} ; a=10.496$ (2) $\AA, b=13.380$ (2) $\AA, c=14.537(6) \AA ; \beta$ $\left.=92.96(3)^{\circ} ; Z=4\right)$. The flexibility of $\mathrm{L}$ is estimated, and the potential of its binuclear complexes for catalytic processes is discussed.
\end{abstract}

\section{Introduction}

Binuclear metal complexes of bridged cyclopentadienyl ligands have recently attracted a lot of attention. This is mainly due to two reasons: Firstly, the two metal centers may show cooperative electronic effects and these com. plexes are thus potential model systems for organometallic polymers that exhibit interesting electric, magnetic, and optical properties. ${ }^{2}$ Secondly, the metal centers may show cooperative chemical effects which have, for example, been envisaged to be useful for homogeneous catalysis. ${ }^{3}$ Flexible bridges impede interactions of both types, because these interactions are primarily dependent on a well-defined stereochemical relationship of the metal centers. Ideally, the two cyclopentadienyl units should be arranged in a sterically fairly fixed manner and at the same time in a moderate to short distance to each other; additionally, the bridging group(s) should allow for potential electron density delocalization.

In this respect, we have investigated the synthesis and structure of binuclear metal complexes derived from the doubly bridged cyclopentadienyl system 1 and its dilithio

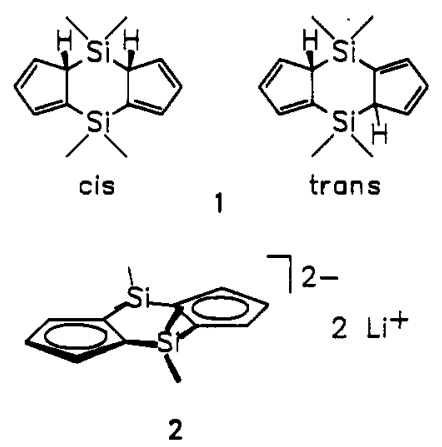

salt 2.4 Meanwhile, compound 2 has also been investigated by Köhler et al. ${ }^{5}$ and has been utilized for the preparation

\footnotetext{
${ }^{+} \mathrm{X}$-ray structure analysis.
}

of mono- and oligonuclear metallocenes. ${ }^{6}$

\section{Results and Discussion}

Ligand 1 seemed to us to fulfill the requirements mentioned above: The two $\mathrm{Cp}$ rings are held in a fairly close position to each other; the system is not very flexible due to the presence of two bridges; furthermore, there is good evidence for $\mathrm{SiMe}_{2}$ units to be able to allow for electronic delocalization. ${ }^{7}$

Compound 1 can be prepared in $47 \%$ yield from $\mathrm{CpSiMe}_{2} \mathrm{Cl}$ following a known procedure ${ }^{8}$ which was modified so as to allow the preparation of $15-20$-g quantities of this substance. In solution two isomers (cis-1 and trans-1) are present in a cis:trans ratio of ca. 1:2, according to ${ }^{1} \mathrm{H}$ NMR spectroscopy. They equilibrate via silatropic rearrangements. ${ }^{9}$ Only the trans isomer crystallizes from solutions. A single-crystal X-ray diffraction study of this isomer shows that the central six-membered ring adopts a chair conformation; the two $\mathrm{Cp}$ units anelated to this ring are nearly planar (the envelope angle is $4.8^{\circ}$ )..$^{10}$

Compound 1 may be deprotonated with 2 equiv of 1 butyllithium to form the dianionic species 2 , which is

(1) Siemeling, U.; Krallmann, R.; Jutzi, P. Presented in part at the IXth International Symposium on Organosilicon Chemistry, Edinburgh, July 1990; Abstract 3.6.

(2) Böhm, M. C. Lect. Notes Chem. 1987, 45

(3) Buzinkai, J. F.; Schrock, R. R. Inorg. Chem. 1989, 28, 2837 and references therein.

(4) Siemeling, U. Doctoral Thesis, Bielefeld, Germany 1989.

(5) Hiermeier, J.; Köhler, F. H.; Müller, G. Organometallics 1991, 10, 1787.

(6) (a) Atzkern, H.; Hiermeier, J.; Köhler, F. H.; Steck, A. J. Organomet. Chem. 1991, 408, 281. (b) Atzkern, H.; Hiermeier, J.; Kanellakopulos, B.; Köhler, F. H.; Müller, G.; Steigelmann, O. J. Chem. Soc., Chem. Commun. 1991, 977. (c) Fritz, M.; Hiermeier, J.; Hertkorn, N.; Köhler, F. H.; Müller, G.; Reber, G.; Steigelmann, O. Chem. Ber. 1991, 124,1531 .

(7) Jutzi, P.; Meier, M.; Dias, H. V. R.; Power, P. P. J. Am. Chem. Soc. $1990,112,4841$ and references therein.

(8) Jones, P. R.; Rozell, J. M., Jr.; Campbell, B. M. Organometallics $1985,4,1321$.

(9) Barton, T. J.; Burns, G. T.; Arnold, E. V.; Clardy, J. Tetrahedron Lett. 1981, 22, 7 .

(10) Belsky, V. K.; Zemlyansky, N. N.; Borisova, I. V.; Kolosova, N. D.; Beletskaya, I. P. Cryst. Struct. Commun. 1982, 11, 497. 


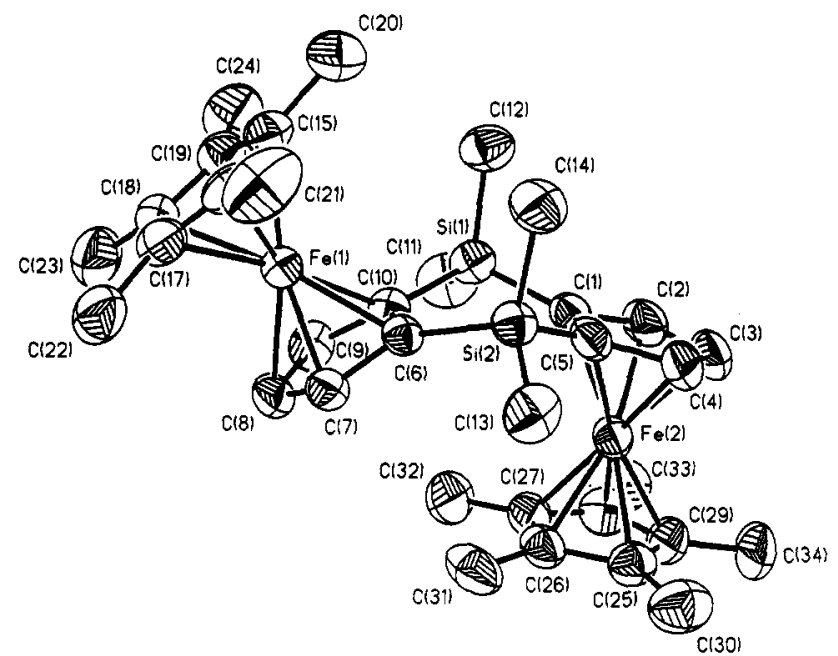

Figure 1. Molecular structure and crystallographers' atomnumbering scheme of compound 5 .

virtually insoluble in all common organic solvents. Its identity was proved by its reaction with 2 equiv of trimethyltin chloride which cleanly leads to the formation of the binuclear tin compound 3 in $71 \%$ yield; 3 forms

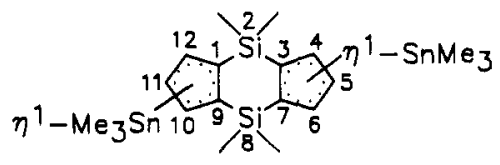

3

slightly air-sensitive, off-white crystals. Similarly, reaction of 2 with 2 equiv of $\mathrm{Cp}^{*} \mathrm{RuCl}^{11}$ gives the binuclear ruthenocene 4 as light yellow, air-stable platelets in $89 \%$

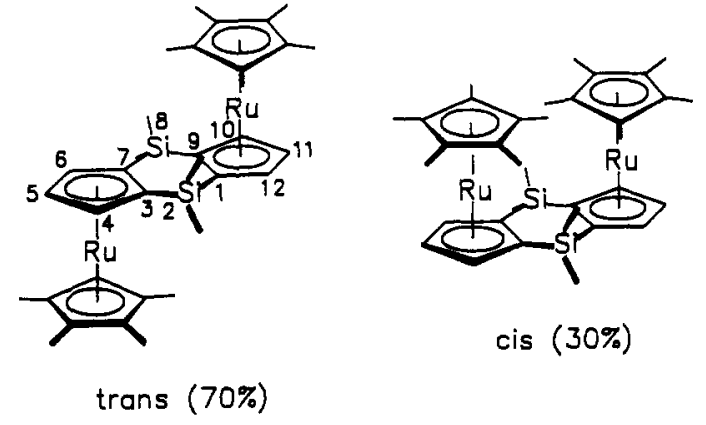

4

yield. Whereas the tin derivative 3 is isolated as the trans isomer exclusively, compound 4 is formed as a cis:trans mixture in a ratio of ca. $3: 7$. The ${ }^{1} \mathrm{H}$ and ${ }^{13} \mathrm{C}$ NMR signals of the bridging $\mathrm{SiMe}_{2}$ units can be used as a probe for distinguishing between cis and trans isomers: Whereas all four methyl groups in the trans isomer of 4 are equivalent, there are two pairs of equivalent methyl groups in the cis isomer; hence, only one methyl signal is observed for trans-4, but two methyl resonances are obtained for cis-4. Essentially the same holds true for the tin compound 3 which, owing to fast stannatropic rearrangements, shows a pseudo- $\eta^{5}$-coordination of the two trimethyltin groups. The protons on the cyclopentadienyl rings give rise to a typical $\mathrm{AX}_{2}$ pattern in the ${ }^{1} \mathrm{H}$ NMR spectrum of 3 . The ${ }^{13} \mathrm{C}$ NMR spectrum shows three resonances for the cyclopentadienyl rings: The four tertiary carbon atoms $\mathrm{C}(4)$,

(11) Fagan, P. J.; Ward, M. D.; Calabrese, J. C. J. Am. Chem. Soc. $1989,111,1698$.
Table I. Atomic Coordinates $\left(\times 10^{4}\right)$ for Compound 5

\begin{tabular}{|c|c|c|c|}
\hline & $x$ & $y$ & $z$ \\
\hline $\mathrm{Fe}(1)$ & $-781(1)$ & $-1827(1)$ & $-4635(1)$ \\
\hline $\mathrm{Fe}(2)$ & $-3277(1)$ & $-584(1)$ & $-2058(1)$ \\
\hline $\mathrm{Si}(1)$ & $-4283(1)$ & $-1318(1)$ & $-3580(1)$ \\
\hline $\operatorname{Si}(2)$ & $-786(1)$ & $-2130(1)$ & $-2846(1)$ \\
\hline $\mathrm{C}(1)$ & $-3981(5)$ & $-1308(2)$ & $-2692(2)$ \\
\hline $\mathrm{C}(2)$ & $-5099(5)$ & $-1103(3)$ & $-2172(2)$ \\
\hline C(3) & $-4362(6)$ & $-1300(3)$ & $-1576(2)$ \\
\hline $\mathrm{C}(4)$ & $-2810(6)$ & $-1635(2)$ & $-1702(2)$ \\
\hline $\mathrm{C}(5)$ & $-2535(5)$ & $-1653(2)$ & $-2393(2)$ \\
\hline$C(6)$ & $-886(4)$ & $-1619(2)$ & $-3631(2)$ \\
\hline$C(7)$ & $333(5)$ & $-1399(2)$ & $-3952(2)$ \\
\hline$C(8)$ & $-327(5)$ & $-826(2)$ & $-4432(2)$ \\
\hline$C(9)$ & $-1962(5)$ & $-788(2)$ & $-4424(2)$ \\
\hline$C(10)$ & $-2343(4)$ & -1275 & $-3937(2)$ \\
\hline$C(11)$ & $-5794(5)$ & $-539(3)$ & $-3886(3)$ \\
\hline $\mathrm{C}(12)$ & $-4936(5)$ & $-2190(2)$ & $-3752(2)$ \\
\hline $\mathrm{C}(13)$ & $1077(5)$ & $-2130(2)$ & $-2418(2)$ \\
\hline$C(14)$ & $-941(5)$ & $-3117(2)$ & $-2916(2)$ \\
\hline $\mathrm{C}(15)$ & $-1035(5)$ & $-2846(2)$ & $-4975(2)$ \\
\hline$C(16)$ & $571(5)$ & $-2803(2)$ & $-4930(2)$ \\
\hline $\mathrm{C}(17)$ & $859(5)$ & -2225 & -5319 \\
\hline$C(18)$ & $-549(5)$ & $-1905(2)$ & $-5625(2)$ \\
\hline $\mathrm{C}(19)$ & $-1731(5)$ & $-2274(2)$ & $-5406(2)$ \\
\hline$C(20)$ & $-1823(6)$ & $-3422(3)$ & $-4700(3)$ \\
\hline$C(21)$ & $1755(6)$ & $-3333(3)$ & $-4529(3)$ \\
\hline $\mathrm{C}(22)$ & $2401(5)$ & -1995 & $-5412(2)$ \\
\hline$C(23)$ & $-768(6)$ & $-1261(3)$ & $-6094(2)$ \\
\hline $\mathrm{C}(24)$ & $-3382(5)$ & -2116 & $-5638(2)$ \\
\hline $\mathrm{C}(25)$ & $-1866(5)$ & $-36(2)$ & $-1561(2)$ \\
\hline $\mathrm{C}(26)$ & $-1635(5)$ & 60 (2) & -2239 \\
\hline $\mathrm{C}(27)$ & $-3096(5)$ & $401(2)$ & $-2498(2)$ \\
\hline $\mathrm{C}(28)$ & $-4239(5)$ & $515(2)$ & $-1987(2)$ \\
\hline $\mathrm{C}(29)$ & $-3469(5)$ & 247 (2) & -1409 \\
\hline $\mathrm{C}(30)$ & $-605(6)$ & -352 (3) & $-1089(2)$ \\
\hline$C(31)$ & $-125(5)$ & $-97(2)$ & $-2598(2)$ \\
\hline$C(32)$ & $-3375(7)$ & $675(3)$ & $-3183(2)$ \\
\hline $\mathrm{C}(33)$ & $-5915(6)$ & 879 (3) & $-2037(3)$ \\
\hline$C(34)$ & $-4216(6)$ & $283(3)$ & $-752(2)$ \\
\hline
\end{tabular}

$C(6), C(10)$, and $C(12)$ give rise to a sharp signal at 130.6 ppm; for the two tertiary carbon atoms $C(5)$ and $C(11)$ a slightly broadened resonance at $123.5 \mathrm{ppm}$ is observed, and the four quaternary carbon atoms $C(1), C(3), C(7)$, and $\mathrm{C}(9)$ give rise to a broad signal at $116.5 \mathrm{ppm}$. The broadness of resonances for $\mathrm{C}(1), \mathrm{C}(3), \mathrm{C}(5), \mathrm{C}(7), \mathrm{C}(9)$, and $\mathrm{C}(11)$, together with their considerable high-field shift with respect to $C(4), C(6), C(10)$, and $C(12)$, indicates that these atoms participate in the migration of the trimethyltin groups. It cannot be ruled out, however, that $\mathrm{C}(4), \mathrm{C}(6)$, $\mathrm{C}(10)$, and $C(12)$ also take part in this migration which can be explained as a series of [1,2] shifts of each of the $\mathrm{SnMe}_{3}$ groups along its respective cyclopentadienyl ring.

The synthesis of the iron analogue of 4 proved to be troublesome. Reaction of 2 with 2 equiv of freshly prepared $\mathrm{Cp} * \mathrm{Fe}(\mathrm{acac})^{12}$ in THF does not lead to a clean formation of the binuclear ferrocene 5 . Instead, a mixture

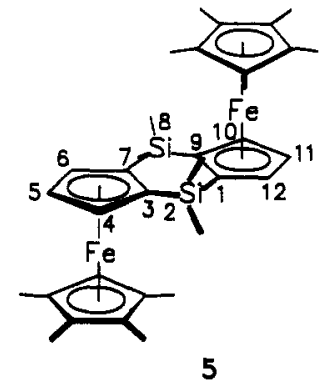

of oligonuclear species is formed, which could not be sep-

(12) Bunel, E. E.; Valle, L.; Manriquez, J. M. Organometallics 1985, 4,1680 . 
Table II. Bond Lengths $(\AA)$ for Compound 5

$\begin{array}{llll}\mathrm{Fe}(1)-\mathrm{C}(6) & 2.103(4) & \mathrm{Fe}(1)-\mathrm{C}(7) & 2.043(4) \\ \mathrm{Fe}(1)-\mathrm{C}(8) & 2.027(4) & \mathrm{Fe}(1)-\mathrm{C}(9) & 2.044(4) \\ \mathrm{Fe}(1)-\mathrm{C}(10) & 2.095(4) & \mathrm{Fe}(1)-\mathrm{C}(15) & 2.079(4) \\ \mathrm{Fe}(1)-\mathrm{C}(16) & 2.044(4) & \mathrm{Fe}(1)-\mathrm{C}(17) & 2.029(4) \\ \mathrm{Fe}(1)-\mathrm{C}(18) & 2.046(4) & \mathrm{Fe}(1)-\mathrm{C}(19) & 2.060(4) \\ \mathrm{Fe}(2)-\mathrm{C}(1) & 2.070(4) & \mathrm{Fe}(2)-\mathrm{C}(2) & 2.040(5) \\ \mathrm{Fe}(2)-\mathrm{C}(3) & 2.026(5) & \mathrm{Fe}(2)-\mathrm{C}(4) & 2.040(4) \\ \mathrm{Fe}(2)-\mathrm{C}(5) & 2.082(4) & \mathrm{Fe}(2)-\mathrm{C}(25) & 2.042(5) \\ \mathrm{Fe}(2)-\mathrm{C}(26) & 2.061(5) & \mathrm{Fe}(2)-\mathrm{C}(27) & 2.064(4) \\ \mathrm{Fe}(2)-\mathrm{C}(28) & 2.049(4) & \mathrm{Fe}(2)-\mathrm{C}(29) & 2.031(4) \\ \mathrm{Si}(1)-\mathrm{C}(1) & 1.851(4) & \mathrm{Si}(1)-\mathrm{C}(10) & 1.856(4) \\ \mathrm{Si}(1)-\mathrm{C}(11) & 1.861(4) & \mathrm{Si}(1)-\mathrm{C}(12) & 1.861(5) \\ \mathrm{Si}(2)-\mathrm{C}(5) & 1.850(4) & \mathrm{Si}(2)-\mathrm{C}(6) & 1.857(4) \\ \mathrm{Si}(2)-\mathrm{C}(13) & 1.863(4) & \mathrm{Si}(2)-\mathrm{C}(14) & 1.871(4) \\ \mathrm{C}(1)-\mathrm{C}(2) & 1.440(6) & \mathrm{C}(1)-\mathrm{C}(5) & 1.440(5) \\ \mathrm{C}(2)-\mathrm{C}(3) & 1.403(7) & \mathrm{C}(3)-\mathrm{C}(4) & 1.396(6) \\ \mathrm{C}(4)-\mathrm{C}(5) & 1.437(6) & \mathrm{C}(6)-\mathrm{C}(7) & 1.428(6) \\ \mathrm{C}(6)-\mathrm{C}(10) & 1.453(5) & \mathrm{C}(7)-\mathrm{C}(8) & 1.410(5) \\ \mathrm{C}(8)-\mathrm{C}(9) & 1.418(6) & \mathrm{C}(9)-\mathrm{C}(10) & 1.423(6) \\ \mathrm{C}(15)-\mathrm{C}(16) & 1.428(6) & \mathrm{C}(15)-\mathrm{C}(19) & 1.421(6) \\ \mathrm{C}(15)-\mathrm{C}(20) & 1.486(7) & \mathrm{C}(16)-\mathrm{C}(17) & 1.392(7) \\ \mathrm{C}(16)-\mathrm{C}(21) & 1.521(6) & \mathrm{C}(17)-\mathrm{C}(18) & 1.407(6) \\ \mathrm{C}(17)-\mathrm{C}(22) & 1.505(7) & \mathrm{C}(18)-\mathrm{C}(19) & 1.416(6) \\ \mathrm{C}(18)-\mathrm{C}(23) & 1.511(6) & \mathrm{C}(19)-\mathrm{C}(24) & 1.497(6) \\ \mathrm{C}(25)-\mathrm{C}(26) & 1.418(6) & \mathrm{C}(25)-\mathrm{C}(29) & 1.425(6) \\ \mathrm{C}(25)-\mathrm{C}(30) & 1.504(6) & \mathrm{C}(26)-\mathrm{C}(27) & 1.402(6) \\ \mathrm{C}(26)-\mathrm{C}(31) & 1.495(6) & \mathrm{C}(27)-\mathrm{C}(28) & 1.427(6) \\ \mathrm{C}(27)-\mathrm{C}(32) & 1.498(6) & \mathrm{C}(28)-\mathrm{C}(29) & 1.411(6) \\ \mathrm{C}(28)-\mathrm{C}(33) & 1.489(6) & \mathrm{C}(29)-\mathrm{C}(34) & 1.489(6) \\ & & & \end{array}$

Table III. Selected Bond Angles (deg) for 5

$\begin{array}{llll}\mathrm{C}(1)-\mathrm{Si}(1)-\mathrm{C}(10) & 104.1(2) & \mathrm{C}(1)-\mathrm{Si}(1)-\mathrm{C}(11) & 114.1(2) \\ \mathrm{C}(10)-\mathrm{Si}(1)-\mathrm{C}(11) & 110.4(2) & \mathrm{C}(1)-\mathrm{Si}(1)-\mathrm{C}(12) & 106.4(2) \\ \mathrm{C}(10)-\mathrm{Si}(1)-\mathrm{C}(12) & 113.8(2) & \mathrm{C}(11)-\mathrm{Si}(1)-\mathrm{C}(12) & 108.2(2) \\ \mathrm{C}(5)-\mathrm{Si}(2)-\mathrm{C}(6) & 103.7(2) & \mathrm{C}(5)-\mathrm{Si}(2)-\mathrm{C}(13) & 113.3(2) \\ \mathrm{C}(6)-\mathrm{Si}(2)-\mathrm{C}(13) & 111.7(2) & \mathrm{C}(5)-\mathrm{Si}(2)-\mathrm{C}(14) & 107.2(2) \\ \mathrm{C}(6)-\mathrm{Si}(2)-\mathrm{C}(14) & 114.7(2) & \mathrm{C}(13)-\mathrm{Si}(2)-\mathrm{C}(14) & 106.3(2) \\ \mathrm{Si}(1)-\mathrm{C}(1)-\mathrm{C}(2) & 129.8(3) & \mathrm{Si}(1)-\mathrm{C}(1)-\mathrm{C}(5) & 122.7(3) \\ \mathrm{C}(2)-\mathrm{C}(1)-\mathrm{C}(5) & 106.5(3) & \mathrm{C}(1)-\mathrm{C}(2)-\mathrm{C}(3) & 109.0(4) \\ \mathrm{C}(2)-\mathrm{C}(3)-\mathrm{C}(4) & 108.4(4) & \mathrm{C}(3)-\mathrm{C}(4)-\mathrm{C}(5) & 109.1(4) \\ \mathrm{Si}(2)-\mathrm{C}(5)-\mathrm{C}(1) & 124.2(3) & \mathrm{Si}(2)-\mathrm{C}(5)-\mathrm{C}(4) & 128.4(3) \\ \mathrm{C}(1)-\mathrm{C}(5)-\mathrm{C}(4) & 107.0(3) & \mathrm{Si}(2)-\mathrm{C}(6)-\mathrm{C}(7) & 127.7(3) \\ \mathrm{Si}(2)-\mathrm{C}(6)-\mathrm{C}(10) & 123.5(3) & \mathrm{C}(7)-\mathrm{C}(6)-\mathrm{C}(10) & 107.2(3) \\ \mathrm{C}(8)-\mathrm{C}(9)-\mathrm{C}(10) & 109.3(3) & \mathrm{Si}(1)-\mathrm{C}(10)-\mathrm{C}(6) & 122.7(3) \\ \mathrm{Si}(1)-\mathrm{C}(10)-\mathrm{C}(9) & 128.7(3) & \mathrm{C}(6)-\mathrm{C}(10)-\mathrm{C}(9) & 106.7(3) \\ \mathrm{C}(16)-\mathrm{C}(15)-\mathrm{C}(19) & 106.6(4) & \mathrm{C}(16)-\mathrm{C}(15)-\mathrm{C}(20) & 128.0(4) \\ \mathrm{C}(19)-\mathrm{C}(15)-\mathrm{C}(20) & 125.0(4) & \mathrm{C}(15)-\mathrm{C}(16)-\mathrm{C}(17) & 109.3(4) \\ \mathrm{C}(15)-\mathrm{C}(16)-\mathrm{C}(21) & 123.7(4) & \mathrm{C}(17)-\mathrm{C}(16)-\mathrm{C}(21) & 126.9(4) \\ \mathrm{C}(16)-\mathrm{C}(17)-\mathrm{C}(18) & 107.6(4) & \mathrm{C}(16)-\mathrm{C}(17)-\mathrm{C}(22) & 126.4(4) \\ \mathrm{C}(18)-\mathrm{C}(17)-\mathrm{C}(22) & 126.0(4) & \mathrm{C}(17)-\mathrm{C}(18)-\mathrm{C}(19) & 108.7(4) \\ \mathrm{C}(17)-\mathrm{C}(18)-\mathrm{C}(23) & 125.5(4) & \mathrm{C}(19)-\mathrm{C}(18)-\mathrm{C}(23) & 125.8(4) \\ \mathrm{C}(15)-\mathrm{C}(19)-\mathrm{C}(18) & 107.7(4) & \mathrm{C}(15)-\mathrm{C}(19)-\mathrm{C}(24) & 127.0(4) \\ \mathrm{C}(18)-\mathrm{C}(19)-\mathrm{C}(24) & 125.1(4) & \mathrm{C}(26)-\mathrm{C}(25)-\mathrm{C}(29) & 107.7(4) \\ \mathrm{C}(26)-\mathrm{C}(25)-\mathrm{C}(30) & 125.7(4) & \mathrm{C}(29)-\mathrm{C}(25)-\mathrm{C}(30) & 126.5(4) \\ \mathrm{C}(25)-\mathrm{C}(26)-\mathrm{C}(27) & 107.9(4) & \mathrm{C}(25)-\mathrm{C}(26)-\mathrm{C}(31) & 125.8(4) \\ \mathrm{C}(27)-\mathrm{C}(26)-\mathrm{C}(31) & 126.9(4) & \mathrm{C}(26)-\mathrm{C}(27)-\mathrm{C}(28) & 108.9(4) \\ \mathrm{C}(26)-\mathrm{C}(27)-\mathrm{C}(32) & 126.0(4) & \mathrm{C}(28)-\mathrm{C}(27)-\mathrm{C}(32) & 124.9(4) \\ \mathrm{C}(27)-\mathrm{C}(28)-\mathrm{C}(29) & 107.1(4) & \mathrm{C}(27)-\mathrm{C}(28)-\mathrm{C}(33) & 127.3(4) \\ \mathrm{C}(29)-\mathrm{C}(28)-\mathrm{C}(33) & 125.6(4) & \mathrm{C}(25)-\mathrm{C}(29)-\mathrm{C}(28) & 108.4(4) \\ \mathrm{C}(25)-\mathrm{C}(29)-\mathrm{C}(34) & 126.6(4) & \mathrm{C}(28)-\mathrm{C}(29)-\mathrm{C}(34) & 125.0(4)\end{array}$

arated so far. Compound 5 can, however, be conveniently prepared by cocomplexation of a $16: 1$ mixture of $\mathrm{Cp} * \mathrm{Li}$ and the dilithio salt 2 in the presence of a stoichiometric amount of iron(II) chloride in THF at low temperatures. After removal of decamethylferrocene by sublimation and recrystallization of the crude product, the binuclear ferrocene 5 is obtained as the trans isomer exclusively in $80 \%$ yield; the compound forms red, air-stable crystals. Crystals suitable for a single-crystal X-ray diffraction study were grown from hexane. The molecular structure of 5 is shown in Figure 1; atomic coordinates are collected in Table I; bond lengths and selected bond angles are collected in Tables II and III. ${ }^{13}$

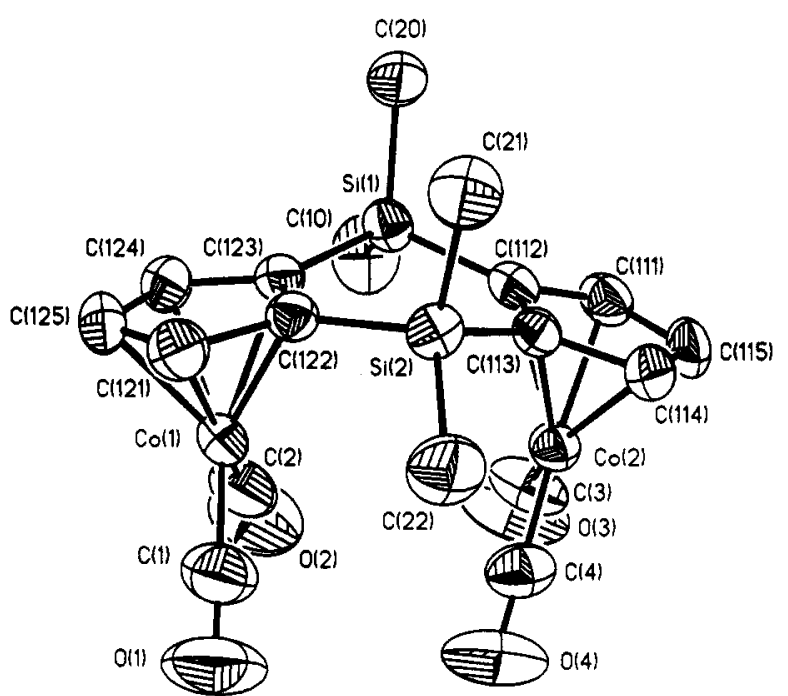

Figure 2. Molecular structure and crystallographers' atomnumbering scheme of compound 6 .

The bridging ligand is not planar. The fold angle between the "best planes" for the two Cp moieties is $44^{\circ}$. The central six-membered ring adopts a fairly flat boat conformation.

When compound 1 is reacted with octacarbonyldicobalt in boiling dichloromethane, the binuclear cobalt complex 6 is obtained in $84 \%$ yield as dark, brownish-red crystals,

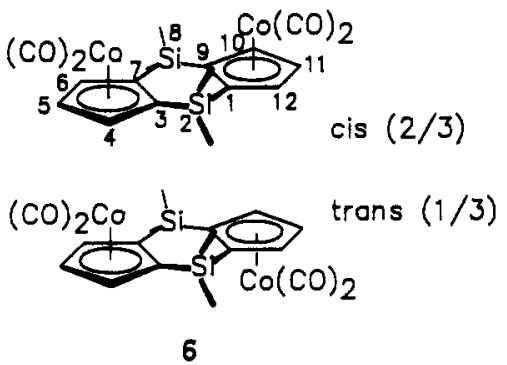

which are slightly air-sensitive. The cis:trans ratio for this product is ca. 2:1.

A single-crystal X-ray diffraction study was performed for this compound. Suitable crystals were grown from hexane, and the crystal that was chosen for the structure investigation proved to be of the cis isomer. The molecular structure is shown in Figure 2; atomic coordinates are collected in Table IV; bond lengths and selected bond angles are collected in Tables V and VI.

Again, the bridging ligand adopts a bent structure with a flat boat conformation of the central six-membered ring. The fold angle between the best planes for the two $\mathrm{Cp}$ units is $23^{\circ}$. The two dicarbonylcobalt fragments are coordinated to the concave surface of the bridging ligand. The intramolecular Co-Co distance is $425 \mathrm{pm}$.

It is possible for the six-membered ring to adopt a much steeper boat conformation than those shown for compounds 5 and 6, leading to fold angles that are considerably larger than those found for these complexes. This is evidenced by the structure of the iron carbonyl complex 7 , which according to IR spectroscopy shows both terminal and bridging carbonyl units ( $\nu_{\mathrm{co}}($ terminal $)=2004,1977$, and $1943 \mathrm{~cm}^{-1} ; \nu_{\mathrm{cO}}($ bridging $\left.)=1766 \mathrm{~cm}^{-1}\right){ }^{14}$ This means

(13) The unit cell contains two independent molecules, whose bonding parameters are identical within the margin of error of the structure determination. Hence, only one molecule is discussed in the text. 


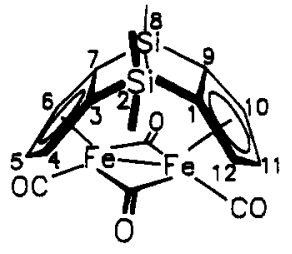

7

that the Fe-Fe bond length is almost certainly less than $260 \mathrm{pm},{ }^{15}$ which is more than $160 \mathrm{pm}$ shorter than the intramolecular $\mathrm{Co}-\mathrm{Co}$ distance found in the cis isomer of 6.

The energy for bending the bridging ligand considerably is so low that it is more than outweighed by the gain in bond energy due to carbonyl bridging. This is by no means always the case; for example, according to IR data carbonyl bridging does not occur in the analogous iron carbonyl complex of tetra-tert-butylpentafulvalene. ${ }^{16}$ Compound 7 is obtained in low yield from the reaction of 1 with pentacarbonyliron. The main products of this reaction are oligo- or polymeric species which could not be separated and fully characterized so far.

In summary, the doubly bridged $\mathrm{Cp}$ system 1 and its dianionic derivative 2 are excellently suited for the preparation of a variety of binuclear metal complexes. Both cis and trans isomers are formed; coordination of large metal-ligand fragments like $C p * M(M=F e, R u)$ seems to favor a trans arrangement for steric reasons. Although the ligand is relatively rigid, the fold angle between the two Cp planes may vary quite substantially for different compounds; hence, the intramolecular distance between two cis-coordinated metal centers may lie in the region of ca. $250-500 \mathrm{pm}$ and possibly an even greater variation can occur. This augurs well for cooperative chemical phenomena that rely on substrate binding by an induced-fit mechanism. For example, the cis isomer of an appropriate early/late heterobimetallic complex should be able to activate small polar molecules like carbon monoxide. ${ }^{17}$

Studies concerning electronic and chemical cooperative effects are currently underway.

\section{Experimental Section}

General Considerations. All reactions were carried out under an atmosphere of purified argon by using standard Schlenk techniques. Solvents and reagents were appropriately dried and purified. The following instruments were used: melting points, Büchi 510 melting point apparatus; NMR spectra, Bruker AM $300\left(300.133 \mathrm{MHz},{ }^{1} \mathrm{H}\right.$, external TMS; $75.453 \mathrm{MHz},{ }^{13} \mathrm{C}$, external TMS; $59.595 \mathrm{MHz},{ }^{20 \mathrm{Si}}$, external TMS; $70.859 \mathrm{MHz},{ }^{59} \mathrm{Co}$, external $\mathrm{K}_{3}\left[\mathrm{Co}(\mathrm{CN})_{6}\right] ; 111.817 \mathrm{MHz},{ }^{119} \mathrm{Sn}$, external $\mathrm{Me}_{4} \mathrm{Sn}$; where necessary, assignment of ${ }^{13} \mathrm{C}$ NMR signals was made using protoncoupled or $J$-modulated spectra); mass spectra, Varian 311 A

(14) All spectral data available are in accord with the monomeric structure shown. The isotopic distribution pattern of the highest molecular mass peak in the mass spectrum of 7 is consistent with the molecular ion of the monomer as opposed to the dication of a putative dimer. Although it cannot be ruled out that the monomeric unit observed in the gas phase is formed during the heating process, we consider this to be very unlikely, since the evaporation temperature was kept well below the decomposition temperature of the compound.

(15) In dodecacarbonyltriiron, the length of the carbonyl-bridged $\mathrm{Fe}-$ $\mathrm{Fe}$ bond is $256 \mathrm{pm}$, whereas the length of the unbridged $\mathrm{Fe}-\mathrm{Fe}$ bond is 268 pm: (a) Cotton, F. A.; Troup, J. M. J. Am. Chem. Soc. 1974, 96, 4155. Other carbonyl-bridged species, too, show Fe-Fe bond lengths that are considerably shorter than $260 \mathrm{pm}$, for example: (b) $\left\{\left[\mathrm{CpFe}(\mathrm{CO})_{2}\right]_{2}\left(d_{\mathrm{Fo}-\mathrm{F}}\right.\right.$ $=254 \mathrm{pm}$ ) Bryan, R. F.; Greene, P. T. J. Chem. Soc. A 1970, 3064. (c) $\left\{\left[\mathrm{C}_{6} \mathrm{H}_{4} \mathrm{Fe}(\mathrm{CO})_{2}\right]_{2} \mathrm{SiMe}_{2}\left(d_{\mathrm{Fo}} \mathrm{Fe}_{\mathrm{F}}=252 \mathrm{pm}\right)\right\}$ Wegner, P. A.; Uski, V. A. Kiester, R. P.; Dabestani, S.; Day, V. W. J. Am. Chem. Soc. 1977, 99, 4846.

(16) Jutzi, P.; Schnittger, J. Chem. Ber. 1989, $122,629$.

(17) For a recent review of early/late heterobimetallics see: Stephan, D. W. Coord. Chem. Rev. 1989, 95, 41.
Table IV. Atomic Coordinates $\left(\times 10^{4}\right)$ for Compound 6

\begin{tabular}{lrrr}
\hline & \multicolumn{1}{c}{$x$} & \multicolumn{1}{c}{$y$} & \multicolumn{1}{c}{$z$} \\
\hline $\mathrm{Co}(1)$ & $829(1)$ & $6560(1)$ & $5079(1)$ \\
$\mathrm{Co}(2)$ & $4717(1)$ & $7428(1)$ & $5399(1)$ \\
$\mathrm{Si}(1)$ & $2470(1)$ & $8318(1)$ & $3699(1)$ \\
$\mathrm{C}(10)$ & $2958(7)$ & $7417(6)$ & $2814(4)$ \\
$\mathrm{C}(20)$ & $2083(5)$ & $9533(4)$ & $3131(4)$ \\
$\mathrm{Si}(2)$ & $1982(1)$ & $\mathbf{8 8 0 8}(1)$ & $6061(1)$ \\
$\mathrm{C}(21)$ & $1544(5)$ & $10157(3)$ & $6056(4)$ \\
$\mathrm{C}(22)$ & $1976(6)$ & $8318(5)$ & $7257(3)$ \\
$\mathrm{C}(111)$ & $5122(3)$ & $8559(3)$ & $4502(3)$ \\
$\mathrm{C}(112)$ & $3763(3)$ & $8531(2)$ & $4599(2)$ \\
$\mathrm{C}(113)$ & $3576(3)$ & $8699(2)$ & $5554(2)$ \\
$\mathrm{C}(114)$ & $4831(4)$ & $8836(3)$ & $6004(3)$ \\
$\mathrm{C}(115)$ & $5749(4)$ & $8775(3)$ & $5359(3)$ \\
$\mathrm{C}(121)$ & $-370(4)$ & $7679(3)$ & $5449(3)$ \\
$\mathrm{C}(122)$ & $848(3)$ & $8122(2)$ & $5257(2)$ \\
$\mathrm{C}(123)$ & $1065(3)$ & $7889(2)$ & $4328(2)$ \\
$\mathrm{C}(124)$ & $-35(4)$ & $7328(3)$ & $3967(3)$ \\
$\mathrm{C}(125)$ & $-915(4)$ & $7230(3)$ & $4641(3)$ \\
$\mathrm{C}(1)$ & $881(5)$ & $5912(3)$ & $6107(4)$ \\
$\mathrm{O}(1)$ & $871(5)$ & $5494(3)$ & $6795(3)$ \\
$\mathrm{C}(2)$ & $1697(5)$ & $5660(3)$ & $4553(3)$ \\
$\mathrm{O}(2)$ & $2276(4)$ & $5060(3)$ & $4197(3)$ \\
$\mathrm{C}(3)$ & $5241(5)$ & $6453(3)$ & $4751(4)$ \\
$\mathrm{O}(3)$ & $5605(5)$ & $5815(3)$ & $4305(3)$ \\
$\mathrm{C}(4)$ & $4351(4)$ & $6660(3)$ & $6292(3)$ \\
$\mathrm{O}(4)$ & $4087(4)$ & $6138(3)$ & $6886(2)$ \\
& & &
\end{tabular}

Table V. Bond Lengths $(A)$ for Compound 6

$\begin{array}{llll}\mathrm{C}(121)-\mathrm{Co}(1) & 2.045(6) & \mathrm{C}(122)-\mathrm{Co}(1) & 2.105(5) \\ \mathrm{C}(123)-\mathrm{Co}(1) & 2.108(5) & \mathrm{C}(124)-\mathrm{Co}(1) & 2.083(6) \\ \mathrm{C}(125)-\mathrm{Co}(1) & 2.107(6) & \mathrm{C}(1)-\mathrm{Co}(1) & 1.726(7) \\ \mathrm{C}(2)-\mathrm{Co}(1) & 1.714(7) & \mathrm{C}(111)-\mathrm{Co}(2) & 2.056(6) \\ \mathrm{C}(112)-\mathrm{Co}(2) & 2.100(5) & \mathrm{C}(113)-\mathrm{Co}(2) & 2.099(5) \\ \mathrm{C}(114)-\mathrm{Co}(2) & 2.079(6) & \mathrm{C}(115)-\mathrm{Co}(2) & 2.105(6) \\ \mathrm{C}(3)-\mathrm{Co}(2) & 1.717(7) & \mathrm{C}(4)-\mathrm{Co}(2) & 1.715(6) \\ \mathrm{C}(10)-\mathrm{Si}(1) & 1.853(7) & \mathrm{C}(20)-\mathrm{Si}(1) & 1.859(7) \\ \mathrm{C}(112)-\mathrm{Si}(1) & 1.859(5) & \mathrm{C}(123)-\mathrm{Si}(1) & 1.866(5) \\ \mathrm{C}(21)-\mathrm{Si}(2) & 1.863(6) & \mathrm{C}(22)-\mathrm{Si}(2) & 1.859(6) \\ \mathrm{C}(113)-\mathrm{Si}(2) & 1.868(5) & \mathrm{C}(122)-\mathrm{Si}(2) & 1.865(5) \\ \mathrm{C}(112)-\mathrm{C}(111) & 1.441(6) & \mathrm{C}(115)-\mathrm{C}(111) & 1.407(7) \\ \mathrm{C}(113)-\mathrm{C}(112) & 1.430(5) & \mathrm{C}(114)-\mathrm{C}(113) & 1.452(6) \\ \mathrm{C}(115)-\mathrm{C}(114) & 1.381(6) & \mathrm{C}(122)-\mathrm{C}(121) & 1.449(6) \\ \mathrm{C}(125)-\mathrm{C}(121) & 1.413(7) & \mathrm{C}(123)-\mathrm{C}(122) & 1.416(5) \\ \mathrm{C}(124)-\mathrm{C}(123) & 1.452(6) & \mathrm{C}(125)-\mathrm{C}(124) & 1.387(7) \\ \mathrm{O}(1)-\mathrm{C}(1) & 1.147(6) & \mathrm{O}(2)-\mathrm{C}(2) & 1.147(6) \\ \mathrm{O}(3)-\mathrm{C}(3) & 1.149(6) & \mathrm{O}(4)-\mathrm{C}(4) & 1.155(6) \\ & & & \end{array}$

Table VI. Selected Bond Angles (deg) for 6

$\begin{array}{lrlr}\mathrm{C}(2)-\mathrm{Co}(1)-\mathrm{C}(1) & 92.2(3) & \mathrm{C}(4)-\mathrm{Co}(2)-\mathrm{C}(3) & 92.9(3) \\ \mathrm{C}(20)-\mathrm{Si}(1)-\mathrm{C}(10) & 108.8(4) & \mathrm{C}(112)-\mathrm{Si}(1)-\mathrm{C}(10) & 111.8(4) \\ \mathrm{C}(112)-\mathrm{Si}(1)-\mathrm{C}(20) & 108.2(3) & \mathrm{C}(123)-\mathrm{Si}(1)-\mathrm{C}(10) & 113.2(4) \\ \mathrm{C}(123)-\mathrm{Si}(1)-\mathrm{C}(20) & 109.0(3) & \mathrm{C}(123)-\mathrm{Si}(1)-\mathrm{C}(112) & 105.6(2) \\ \mathrm{C}(22)-\mathrm{Si}(2)-\mathrm{C}(21) & 109.4(4) & \mathrm{C}(113)-\mathrm{Si}(2)-\mathrm{C}(21) & 107.4(3) \\ \mathrm{C}(113)-\mathrm{Si}(2)-\mathrm{C}(22) & 112.8(3) & \mathrm{C}(122)-\mathrm{Si}(2)-\mathrm{C}(21) & 109.0(3) \\ \mathrm{C}(122)-\mathrm{Si}(2)-\mathrm{C}(22) & 112.3(3) & \mathrm{C}(122)-\mathrm{Si}(2)-\mathrm{C}(113) & 105.7(2) \\ \mathrm{C}(115)-\mathrm{C}(111)-\mathrm{C}(112) & 109.8(4) & \mathrm{C}(111)-\mathrm{C}(112)-\mathrm{Si}(1) & 128.7(4) \\ \mathrm{C}(113)-\mathrm{C}(112)-\mathrm{Si}(1) & 125.2(3) & \mathrm{C}(113)-\mathrm{C}(112)-\mathrm{C}(111) & 106.1(4) \\ \mathrm{C}(112)-\mathrm{C}(113)-\mathrm{Si}(2) & 124.5(3) & \mathrm{C}(114)-\mathrm{C}(113)-\mathrm{Si}(2) & 128.5(4) \\ \mathrm{C}(114)-\mathrm{C}(113)-\mathrm{C}(112) & 106.8(4) & \mathrm{C}(115)-\mathrm{C}(114)-\mathrm{C}(113) & 109.6(5) \\ \mathrm{C}(114)-\mathrm{C}(115)-\mathrm{C}(111) & 107.6(4) & \mathrm{C}(125)-\mathrm{C}(121)-\mathrm{C}(122) & 109.7(4) \\ \mathrm{C}(121)-\mathrm{C}(122)-\mathrm{Si}(2) & 128.4(4) & \mathrm{C}(123)-\mathrm{C}(122)-\mathrm{Si}(2) & 125.3(3) \\ \mathrm{C}(123)-\mathrm{C}(122)-\mathrm{C}(121) & 106.2(4) & \mathrm{C}(122)-\mathrm{C}(123)-\mathrm{Si}(1) & 124.7(3) \\ \mathrm{C}(124)-\mathrm{C}(123)-\mathrm{Si}(1) & 128.0(4) & \mathrm{C}(124)-\mathrm{C}(123)-\mathrm{C}(122) & 107.2(4) \\ \mathrm{C}(125)-\mathrm{C}(124)-\mathrm{C}(123) & 109.9(5) & \mathrm{C}(124)-\mathrm{C}(125)-\mathrm{C}(121) & 106.9(4) \\ \mathrm{O}(1)-\mathrm{C}(1)-\mathrm{Co}(1) & 177.4(5) & \mathrm{O}(2)-\mathrm{C}(2)-\mathrm{Co}(1) & 179.7(3) \\ \mathrm{O}(3)-\mathrm{C}(3)-\mathrm{Co}(2) & 178.5(4) & \mathrm{O}(4)-\mathrm{C}(4)-\mathrm{Co}(2) & 179.0(4)\end{array}$

(70-eV, 300- $\mu \mathrm{A}$ emission; only characteristic fragments are listed); IR spectra (CsI pellets), Mattson Polaris FTIR spectrophotometer. Elemental analyses were carried out by "Mikroanalytisches Laboratorium Beller" (Göttingen, FRG) or by the microanalytical laboratory of the Universität Bielefeld.

Chlorocyclopentadienyldimethylsilane. A 400-mL aliquot of a $1.60 \mathrm{M}$ solution of 1-butyllithium in hexane $(640 \mathrm{mmol})$ is added dropwise with stirring to a solution of $43.0 \mathrm{~g}(650 \mathrm{mmol})$ of cyclopentadiene in $400 \mathrm{~mL}$ of THF at $0^{\circ} \mathrm{C}$. After stirring for $2 \mathrm{~h}$ at this temperature, $200 \mathrm{~mL}(1.65 \mathrm{~mol})$ of dichlorodi- 
methylsilane is added, and the mixture is refluxed for $60 \mathrm{~h}$. Volatiles are removed at water aspirator pressure, $100 \mathrm{~mL}$ of light petroleum ether is added, and the white, insoluble material (mainly lithium chloride) is removed by filtration and washed with light petroleum ether $(50 \mathrm{~mL})$. Volatiles are removed from the pale yellow filtrate at water aspirator pressure, and the remaining light yellow oil is distilled using a short Vigreux column to yield 83.1 $\mathrm{g}(83 \%)$ of product as a colorless liquid, bp $48-50{ }^{\circ} \mathrm{C} / 20 \mathrm{mbar}$ $\left(46-51{ }^{\circ} \mathrm{C} / 20 \mathrm{mbar}\right){ }^{18}$

2,2,8,8-Tetramethyl-2,8-disilatricyclo $\left[7.3 .0 .0^{3,7}\right]$ dodeca$3,5,9,11$-tetraene (1). A $200-\mathrm{mL}$ aliquot of a $1.50 \mathrm{M}$ solution of tert-butyllithium in pentane $(300 \mathrm{mmol})$ is added dropwise with stirring over a period of $2.5 \mathrm{~h}$ to a solution of $48.0 \mathrm{~g}$ ( $302 \mathrm{mmol}$ ) of chlorocyclopentadienyldimethylsilane in $630 \mathrm{~mL}$ of diethyl ether at $-100^{\circ} \mathrm{C}$. Subsequently, $31.3 \mathrm{~g}(300 \mathrm{mmol})$ of methoxytrimethylsilane is added, and the mixture is warmed to room temperature overnight to give a colorless solution and white precipitate. The volume of the mixture is reduced to ca. $200 \mathrm{~mL}$ in vacuo, $150 \mathrm{~mL}$ of $n$-pentane is added, and the precipitate is filtered off and washed with $n$-pentane $(2 \times 50 \mathrm{~mL})$. Volatiles are removed from the filtrate in vacuo to give a turbid, viscous, pale yellow oil. The product is isolated from this oil by distillation/sublimation at a bath temperature of $60-150^{\circ} \mathrm{C}$. The crude product thus obtained is recrystallized from $n$-hexane and is subsequently sublimed at $10^{-3} \mathrm{mbar}$ to give $17.3 \mathrm{~g}$ (47\% with respect to tertbutyllithium) of white, air-stable crystals, $\mathrm{mp} 103-106^{\circ} \mathrm{C}(102-104$ $\left.{ }^{\circ} \mathrm{C}\right) .{ }^{8}{ }^{1} \mathrm{H} \mathrm{NMR}\left(\mathrm{CDCl}_{3}\right)$ : trans isomer $\delta-0.50(\mathrm{~s}, 6 \mathrm{H}, \mathrm{Me}), 0.52$ $(\mathrm{s}, 6 \mathrm{H}, \mathrm{Me}), 3.51(\mathrm{~s}, 2 \mathrm{H}$, allylic $\mathrm{H}), 6.65(\mathrm{~m}, 2 \mathrm{H}$, vinylic $\mathrm{H}), 6.80$ (" $\mathrm{t}$ ", $2 \mathrm{H}$, vinylic $\mathrm{H}$ ), 6.97 (" $\mathrm{t}$ ", $2 \mathrm{H}$, vinylic $\mathrm{H}$ ); cis isomer $\delta-1.39$ (s, 3 H, Me), 0.31 (s, $3 \mathrm{H}, \mathrm{Me}), 0.46(\mathrm{~s}, 3 \mathrm{H}, \mathrm{Me}), 0.49(\mathrm{~s}, 3 \mathrm{H}, \mathrm{Me})$, $3.80(\mathrm{~s}, 2 \mathrm{H}$, allylic $\mathrm{H}), 6.55(\mathrm{~m}, 2 \mathrm{H}$, vinylic $\mathrm{H}), 6.72(\mathrm{~m}, 2 \mathrm{H}$, vinylic $\mathrm{H}), 6.81$ (“d”, $2 \mathrm{H}$, vinylic $\mathrm{H}),{ }^{13} \mathrm{C}\left\{{ }^{1} \mathrm{H}\right\} \mathrm{NMR}\left(\mathrm{CDCl}_{3}\right)$ : trans isomer $\delta-7.1(\mathrm{Me}),-2.8(\mathrm{Me}), 57.4$ (allylic C), 130.9 (vinylic $\mathrm{CH}$ ), 138.5 (vinylic $\mathrm{CH}$ ), 139.4 (vinylic $\mathrm{CH}$ ), 145.7 (vinylic $\mathrm{C}$ ); cis isomer $\delta$ $-15.8(\mathrm{Me}),-5.4(\mathrm{Me}), 0.9(\mathrm{Me}), 55.5$ (allylic C), 131.0 (vinylic $\mathrm{CH}$ ), 137.0 (vinylic $\mathrm{CH}$ ), 138.3 (vinylic $\mathrm{CH}$ ), 148.0 (vinylic $\mathrm{C}$ ).

2,2,8,8-Tetramethyl-1,7-bis ( $\eta^{1}$-trimethylstannyl)-2,8-disilatricyclo[7.3.0.0 $\left.{ }^{3,7}\right]$ dodeca-3,5,9,11-tetraene (3). A 10.0-mL aliquot of a $1.60 \mathrm{M}$ solution of 1-butyllithium in hexane (16.0 $\mathrm{mmol})$ is added dropwise with stirring to a solution of $1.96 \mathrm{~g}(8.02$ mmol) of 1 in $50 \mathrm{~mL}$ of THF. After $1.5 \mathrm{~h}$ a solution of $3.20 \mathrm{~g}$ (16.1 mmol) of trimethyltin chloride in $15 \mathrm{~mL}$ of THF is added, whereupon the white precipitate of 2 quickly dissolves to give a pale yellow solution. After $1 \mathrm{~h}$ volatiles are removed in vacuo, and the remaining solid is extracted with $30 \mathrm{~mL}$ of $n$-hexane. Insoluble material is removed by filtration. The pale yellow filtrate is reduced to ca. $10 \mathrm{~mL}$ in vacuo and stored at $-30^{\circ} \mathrm{C}$ to give 3.24 $\mathrm{g}(71 \%)$ of off-white crystals, $\mathrm{mp} 84-87^{\circ} \mathrm{C} .{ }^{1} \mathrm{H} \mathrm{NMR}\left(\mathrm{CDCl}_{3}\right)$ : $\delta-0.12\left(\mathrm{~s}, 18 \mathrm{H}, \mathrm{SnMe}_{3}\right.$, tin satellites are observed with ${ }^{2} J$ $\left.\left({ }^{119} \mathrm{Sn}-{ }^{1} \mathrm{H}\right)=53 \mathrm{~Hz}\right), 0.10\left(\mathrm{~s}, 12 \mathrm{H}, \mathrm{SiMe}_{2}\right), 6.63\left(\mathrm{t},{ }^{3} J=2.9 \mathrm{~Hz}\right.$ $2 \mathrm{H}, \mathrm{H}(5), \mathrm{H}(11)), 6.70\left(\mathrm{~d},{ }^{3} \mathrm{~J}=2.9 \mathrm{~Hz}, 4 \mathrm{H}, \mathrm{H}(4), \mathrm{H}(6), \mathrm{H}(10)\right.$, $\mathrm{H}(12)) .{ }^{13} \mathrm{C}\left({ }^{1} \mathrm{H}\right\}$ NMR $\left(\mathrm{CDCl}_{3}\right): \delta-6.7\left(\mathrm{SnMe}_{3}\right.$; tin satellites are observed with $\left.{ }^{1} J\left({ }^{119} \mathrm{Sn}-{ }^{13} \mathrm{C}\right)=336 \mathrm{~Hz}\right),-0.3\left(\mathrm{SiMe}_{2}\right), 116.5(\mathrm{C}(1)$, $\mathrm{C}(3), \mathrm{C}(7), \mathrm{C}(9)), 123.5$ (C(5), C(11)), 130.6 (C(4), C(6), C(10), $\mathrm{C}(12)) .{ }^{29} \mathrm{Si}$ NMR $\left(\mathrm{CDCl}_{3}\right): \delta-15.6 .{ }^{119} \mathrm{Sn} \mathrm{NMR}\left(\mathrm{CDCl}_{3}\right): \delta 19.2$ $\left(\nu_{1 / 2}=18 \mathrm{~Hz}\right)$. MS: $m / e(\%) 572\left(\mathrm{M}^{+}\left(2 \times{ }^{120} \mathrm{Sn}\right), 7\right), 557\left(\left[\mathrm{M}^{+}(2\right.\right.$ $\left.\left.\left.\times{ }^{120} \mathrm{Sn}\right)-\mathrm{Me}\right], 19\right), 392\left(\left[\mathrm{M}^{+}\left(2 \times{ }^{120} \mathrm{Sn}\right)-\mathrm{Me}-{ }^{120} \mathrm{SnMe}_{3}\right], 13\right)$ $377\left(\left[\mathrm{M}^{+}\left(2 \times{ }^{120} \mathrm{Sn}\right)-2 \mathrm{Me}-{ }^{120} \mathrm{SnMe}_{3}\right], 47\right), 362\left(\left[\mathrm{M}^{+}\left(2 \times{ }^{120} \mathrm{Sn}\right)\right.\right.$ $\left.\left.-3 \mathrm{Me}-{ }^{120} \mathrm{SnMe}_{3}\right], 98\right), 165\left({ }^{120} \mathrm{SnMe}_{3}, 100\right)$. Anal. Calcd for $\mathrm{C}_{20} \mathrm{H}_{36} \mathrm{Si}_{2} \mathrm{Sn}_{2}$ (570.1): C, 42.14; $\mathrm{H}, 6.37$. Found: $\mathrm{C}, 42.12 ; \mathrm{H}, 6.50$. Bis $\left(\eta^{5}-1,2,3,4,5\right.$-pentamethyl-2,4-cyclopentadien-1-yl $)[\mu$ $\{(1) 9-12-\eta: 3-7-\eta\}-2,2,8,8-$ tetramethyl-2,8-disilatricyclo[7,3.0.0 $\left.0^{3,7}\right]$ dodeca-3,5,9,11-tetraene-1,7-diyl]diruthenium(II) (4). A suspension of $7.81 \mathrm{mmol}$ of the dilithio salt of 2 is prepared in $80 \mathrm{~mL}$ of THF from $1.91 \mathrm{~g}(7.81 \mathrm{mmol})$ of 1 and $10.0 \mathrm{~mL}$ of a $1.56 \mathrm{M}$ solution of 1-butyllithium in hexane $(15.6 \mathrm{mmol})$. This suspension is added dropwise with stirring to a suspension of 4.26 $\mathrm{g}$ (15.5 mmol) of chloro(pentamethylcyclopentadienyl)ruthenium(II) ${ }^{11}$ in $50 \mathrm{~mL}$ of THF at $-100^{\circ} \mathrm{C}$. The mixture is warmed to room temperature overnight, volatiles are removed in vacuo, and the remaining solid is extracted with $150 \mathrm{~mL}$ of $n$-hexane. Insoluble material is removed by filtration through a $1-\mathrm{cm}$ layer of Florisil, and the filtrate is stored at $-60^{\circ} \mathrm{C}$ to yield $4.96 \mathrm{~g}(89 \%)$

(18) Klouras, N.; Köpf, H. Monatsh. Chem. 1981, 112, 887. of pale yellow platelets, $\mathrm{mp} 239-264^{\circ} \mathrm{C} .{ }^{1} \mathrm{H} \mathrm{NMR}\left(\mathrm{CDCl}_{3}\right)$ : trans isomer $\delta 0.29\left(\mathrm{~s}, 12 \mathrm{H}, \mathrm{SiMe}_{2}\right), 1.78\left(\mathrm{~s}, 30 \mathrm{H}, \mathrm{Cp}^{*}\right), 4.21(\mathrm{~m}, 6 \mathrm{H}$, $\mathrm{CH})$; cis isomer $\delta 0.22\left(\mathrm{~s}, 6 \mathrm{H}, \mathrm{SiMe}_{2}\right), 0.46\left(\mathrm{~s}, 6 \mathrm{H}, \mathrm{SiMe}_{2}\right), 1.92$ (s, 30 H, Cp*), $4.14(\mathrm{~m}, 2 \mathrm{H}, \mathrm{CH}), 4.22(\mathrm{~m}, 4 \mathrm{H}, \mathrm{CH}) .{ }^{13} \mathrm{C}\left\{{ }^{1} \mathrm{H}\right\} \mathrm{NMR}$ $\left(\mathrm{C}_{6} \mathrm{D}_{6}\right)$ : trans isomer $\delta 2.0\left(\mathrm{SiMe}_{2}\right), 12.6\left(\mathrm{C}_{5} \mathrm{Me}_{5}\right), 77.5(\mathrm{C}(5), \mathrm{C}(11))$, 79.2 (C(4), C(6), C(10), C(12)), 82.5 (C(1), C(3), C(7), C(9)), 85.0 $\left(C_{5} \mathrm{Me}_{5}\right)$; cis isomer $\delta 0.7\left(\mathrm{SiMe}_{2}\right), 6.2\left(\mathrm{SiMe}_{2}\right), 12.9\left(\mathrm{C}_{5} \mathrm{Me}_{5}\right), 76.8$ (C(5), C(11)), 79.5 (C(4), C(6), C(10), C(12)), 82.5 (C(1), C(3), C(7), $\mathrm{C}(9)), 85.0\left(C_{5} \mathrm{Me}_{5}\right)$. ${ }^{29} \mathrm{Si}$ NMR $\left(\mathrm{C}_{6} \mathrm{D}_{6}\right)$ : trans isomer $\delta-9.2$; cis isomer $\delta$-7.4. IR $\left(\mathrm{cm}^{-1}\right)$ : $3090(\mathrm{w}), 3072(\mathrm{w}), 2965(\mathrm{~m}), 2902(\mathrm{~m})$, $2853(\mathrm{w}), 821(\mathrm{~s}), 808(\mathrm{~s}), 768(\mathrm{~m})$. MS: $m / e(\%) 716\left(\mathrm{M}^{+}(2 \times\right.$ $\left.\left.{ }^{102} \mathrm{Ru}\right), 100\right), 358\left(\mathrm{M}^{2+}\left(2 \times{ }^{102} \mathrm{Ru}\right), 27\right)$. Anal. Calcd for $\mathrm{C}_{34} \mathrm{H}_{48^{-}}$ $\mathrm{Ru}_{2} \mathrm{Si}_{2}$ (715.1): C, 57.11; H, 6.77. Found: C, 57.67; H, 6.54.

Bis $\left(\eta^{5}-1,2,3,4,5\right.$-pentamethyl-2,4-cyclopentadien-1-yl)[trans- $\mu-\{(1) 9-12-\eta ; 3-7-\eta\}-2,2,8,8-$ tetramethyl-2,8-disilatricyclo[7.3.0.0 $\left.{ }^{3,7}\right]$ dodeca-3,5,9,11-tetraene-1,7-diyl]diiron(II) (5). A $9.54-\mathrm{g}(70.0-\mathrm{mmol})$ sample of 1,2,3,4,5-pentamethylcyclopentadiene and $1.10 \mathrm{~g}(4.50 \mathrm{mmol})$ of 1 in $250 \mathrm{~mL}$ of THF are lithiated by dropwise addition of $50.0 \mathrm{~mL}$ of a $1.58 \mathrm{M}$ solution of 1-butyllithium in hexane $(79.0 \mathrm{mmol})$. The mixture is cooled to $-110^{\circ} \mathrm{C}$, and a suspension of $5.00 \mathrm{~g}(39.5 \mathrm{mmol})$ of iron(II) chloride in $50 \mathrm{~mL}$ of THF is added via syringe. After warming to room temperature overnight, volatiles are removed in vacuo. The solid orange residue is extracted with $100 \mathrm{~mL}$ of $n$-hexane, and insoluble material is removed by filtration through a $3-\mathrm{cm}$ layer of Florisil and is subsequently washed with $n$-hexane $(2 \times$ $30 \mathrm{~mL}$ ). Volatiles are removed from the filtrate to leave a light orange powder, from which decamethylferrocene is removed by sublimation at $10^{-3} \mathrm{mbar}$. The remaining crude product is recrystallized from $n$-hexane to yield $2.25 \mathrm{~g}(80 \%)$ of large, red crystals, mp $243-245^{\circ} \mathrm{C} .{ }^{1} \mathrm{H}$ NMR $\left(\mathrm{CDCl}_{3}\right): \delta 0.40(\mathrm{~s}, 12 \mathrm{H}$; $\mathrm{SiMe}_{2}$ ), 1.52 (s, $30 \mathrm{H}, \mathrm{Cp} *$ ), 3.85 (br s, $4 \mathrm{H}, \mathrm{H}(4), \mathrm{H}(6), \mathrm{H}(10)$, $\mathrm{H}(12)), 3.98$ (br s, $2 \mathrm{H}, \mathrm{H}(5), \mathrm{H}(11)) .{ }^{13} \mathrm{C}\left\{{ }^{1} \mathrm{H}\right\}$ NMR $\left(\mathrm{C}_{6} \mathrm{D}_{6}\right): \delta 2.1$ $\left(\mathrm{SiMe}_{2}\right), 11.9\left(\mathrm{C}_{5} \mathrm{Me}_{5}\right), 77.9(\mathrm{C}(5), \mathrm{C}(11)), 78.9(\mathrm{C}(4), \mathrm{C}(6), \mathrm{C}(10)$, $\mathrm{C}(12)), 79.1$ (C(1), C(3), C(7), C(9)), $79.7\left(C_{5} \mathrm{Me}_{5}\right)$. ${ }^{29} \mathrm{Si}$ NMR $\left(\mathrm{C}_{6} \mathrm{D}_{6}\right): \delta-7.8$. IR $\left(\mathrm{cm}^{-1}\right): 3077(\mathrm{w}), 3063(\mathrm{w}), 2974(\mathrm{~m}), 2960(\mathrm{~m})$, $2906(\mathrm{~m}), 2858(\mathrm{w}), 827(\mathrm{~s}), 813(\mathrm{~s}), 767(\mathrm{~m}), 448(\mathrm{~m}), 417(\mathrm{~m})$, $392(\mathrm{~m})$. MS: $m / e(\%) 624\left(\mathrm{M}^{+}, 100\right), 312\left(\mathrm{M}^{2+}, 23\right)$. Anal. Calcd for $\mathrm{C}_{34} \mathrm{H}_{48} \mathrm{Fe}_{2} \mathrm{Si}_{2}$ (624.6): C, 65.38; H, 7.75. Found: $\mathrm{C}, 65.50 ; \mathrm{H}$, 7.84 .

Tetracarbonyl $[\mu-\{(1) 9-12-\eta: 3-7-\eta\}-2,2,8,8-$ tetramethyl-2,8disilatricyclo[7.3.0.0 ${ }^{3,7}$ ]dodeca-3,5,9,11-tetraene-1,7-diyl]dicobalt(I) (6). A solution of $5.18 \mathrm{~g}(15.1 \mathrm{mmol})$ of octacarbonyldicobalt, $3.70 \mathrm{~g}(15.1 \mathrm{mmol})$ of 1 , and $2.2 \mathrm{~mL}$ of $1,3-$ cyclohexadiene in $35 \mathrm{~mL}$ of dichloromethane is refluxed for $6 \mathrm{~h}$. After cooling to room temperature, the mixture is allowed to stand overnight. Volatiles are removed in vacuo, and the remaining brownish-red solid is dissolved in $40 \mathrm{~mL}$ of $n$-hexane. The solution is filtered through a 2-cm layer of Florisil which is subsequently washed with $10 \mathrm{~mL}$ of $n$-hexane; the filtrate is concentrated to ca. $10 \mathrm{~mL}$ and stored at $-30^{\circ} \mathrm{C}$ to afford brownish-red crystals of crude product. Recrystallization from a minimal amount of $n$-hexane yields $6.05 \mathrm{~g}(84 \%)$ of pure product, $\mathrm{mp} 118-121^{\circ} \mathrm{C}$. ${ }^{1} \mathrm{H}$ NMR $\left(\mathrm{C}_{6} \mathrm{D}_{6}\right)$ : trans isomer $\delta 0.34\left(\mathrm{~s}, 12 \mathrm{H}, \mathrm{SiMe}_{2}\right), 4.66(\mathrm{~d}$, $\left.{ }^{3} J=2.3 \mathrm{~Hz}, 4 \mathrm{H}, \mathrm{H}(4), \mathrm{H}(6), \mathrm{H}(10), \mathrm{H}(12)\right), 4.98\left(\mathrm{t},{ }^{3} J=2.3 \mathrm{~Hz}\right.$, $2 \mathrm{H}, \mathrm{H}(5), \mathrm{H}(11))$; cis isomer $\delta 0.09\left(\mathrm{~s}, 6 \mathrm{H}, \mathrm{SiMe}_{2}\right), 0.48(\mathrm{~s}, 6 \mathrm{H}$, $\left.\mathrm{SiMe}_{2}\right), 4.58\left(\mathrm{~d},{ }^{3} J=2.3 \mathrm{~Hz}, 4 \mathrm{H}, \mathrm{H}(4), \mathrm{H}(6), \mathrm{H}(10), \mathrm{H}(12)\right), 5.09$ $\left(\mathrm{t},{ }^{3} J=2.3 \mathrm{~Hz}, 2 \mathrm{H}, \mathrm{H}(5), \mathrm{H}(11)\right)$. ${ }^{13} \mathrm{C}\left\{{ }^{1} \mathrm{H}\right\} \mathrm{NMR}\left(\mathrm{C}_{6} \mathrm{D}_{6}\right)$ : trans isomer $\delta 1.8(\mathrm{Me}), 90.6(\mathrm{C}(5), \mathrm{C}(11)), 91.1(\mathrm{C}(4), \mathrm{C}(6), \mathrm{C}(10), \mathrm{C}(12))$, $98.2(\mathrm{C}(1), \mathrm{C}(3), \mathrm{C}(7), \mathrm{C}(9)), 204.6(\mathrm{CO})$; cis isomer $\delta-0.3(\mathrm{Me})$, $2.1(\mathrm{Me}), 90.0(\mathrm{C}(4), \mathrm{C}(6), \mathrm{C}(10), \mathrm{C}(12)), 91.1(\mathrm{C}(5), \mathrm{C}(11)), 97.6$ (C(1), $\mathrm{C}(3), \mathrm{C}(7), \mathrm{C}(9)), 204.6(\mathrm{CO}) .{ }^{29} \mathrm{Si} \mathrm{NMR}\left(\mathrm{C}_{6} \mathrm{D}_{6}\right)$ : trans isomer $\delta-13.9$; cis isomer $\delta-15.0$. ${ }^{59} \mathrm{Co}$ NMR $\left(\mathrm{C}_{6} \mathrm{D}_{6}\right): \delta-2630$ $\left(\nu_{1 / 2}=23000 \mathrm{~Hz}\right)$. IR $\left(\mathrm{cm}^{-1}\right): 3108(\mathrm{vw}), 3076(\mathrm{vw}), 2958(\mathrm{sh}, \mathrm{w})$, $2903(\mathrm{vw}), 2022(\mathrm{~s}), 1974(\mathrm{~s}), 1962(\mathrm{~s}), 823(\mathrm{~m}), 774(\mathrm{~m}), 619(\mathrm{~m})$. MS: $m / e(\%) 472\left(\mathrm{M}^{+}, 21\right), 444\left(\left[\mathrm{M}^{+}-\mathrm{CO}\right], 4\right), 416\left(\left[\mathrm{M}^{+}-2 \mathrm{CO}\right]\right.$, $41), 388\left(\left[\mathrm{M}^{+}-3 \mathrm{CO}\right], 17\right), 360\left(\left[\mathrm{M}^{+}-4 \mathrm{CO}\right], 100\right), 301\left(\left[\mathrm{M}^{+}-4 \mathrm{CO}\right.\right.$ - Co], 46). Anal. Calcd for $\mathrm{C}_{18} \mathrm{H}_{18} \mathrm{Co}_{2} \mathrm{O}_{4} \mathrm{Si}_{2}$ (472.4): $\mathrm{C}, 45.77 ; \mathrm{H}$, 3.84. Found: $\mathrm{C}, 45.96 ; \mathrm{H}, 4.01$.

Bis ( $\mu$-carbonyl)dicarbonyl[ cis $-\mu-\{(1) 9-12-\eta: 3-7-\eta\}-2,2,8,8-$ tetramethyl-2,8-disilatricyclo[7.3.0.0 $\left.0^{3,7}\right]$ dodeca-3,5,9,11-tetraene-1,7-diyl]diiron(I) (7). A solution of $2.45 \mathrm{~g}(10.0 \mathrm{mmol})$ of 1 and $3.92 \mathrm{~g} \mathrm{(20.0} \mathrm{mmol)} \mathrm{of} \mathrm{pentacarbonyliron} \mathrm{in} 120 \mathrm{~mL}$ of methylcyclohexane is refluxed for $44 \mathrm{~h}$; after 6,18 , and $26 \mathrm{~h}, 3.20$ $\mathrm{g}(16.3 \mathrm{mmol})$ of pentacarbonyliron is added. After cooling to room temperature, the precipitate is separated off, and the clear 
Table VII. Crystal Data, Intensity Measurement, and Refinement Parameters for 5

empirical formula: $\mathrm{C}_{34} \mathrm{H}_{48} \mathrm{Fe}_{2} \mathrm{Si}_{2}$

$\mathrm{fw}=624.6$

cryst syst: triclinic $(Z=4)$

space group: $P \overline{\mathbf{1}}$

$a=8.7443$ (13) $\AA, b=18.561$ (3) $\AA, c=20.576$ (4) $\AA$

$\alpha=89.340(13)^{\circ}, \beta=89.160(13)^{\circ}, \gamma=78.300(12)^{\circ}$

$V=3269.6(9) \AA^{3}$

$d_{\text {caled }}=1.27 \mathrm{~g} \mathrm{~cm}^{-3}$

$\mu($ Mo $\mathrm{K} \alpha)=0.98 \mathrm{~mm}^{-1}$

$F(000)=1328$

radiatn: Mo K $\alpha$ (graphite monochromator, $\lambda=0.71073 \AA$ )

scan mode: $\omega$-scan

scan range $(2 \theta): 4.0-54^{\circ}$

scan speed: variable; $6.0-30.0^{\circ} / \mathrm{min}$ in $\omega$

bkgd measurement: stationary crystal and stationary counter at

beginning and end of scan, each for $35.0 \%$ of total scan time

temp $=298 \mathrm{~K}$

check reflctns: 3 reflctns every 100 reflctns

index ranges: $0 \leq h \leq 11,-23 \leq k \leq 23,-26 \leq l \leq 26$

abs corrn: semiempirical

$\min / \max$ trans: $0.0947 / 0.1319$

no. of reflctns colled: 15569

no. of ind reflctns: $14176\left(R_{\text {int }}=0.83 \%\right)$

no. of obsd reflctns: $11058\left(F_{\mathrm{o}}>4.0 \sigma\left(F_{\mathrm{o}}\right)\right)$

no. of variables: 685

$R=0.0475^{a}$

$R_{\mathrm{w}}=0.0453^{\circ}$

${ }^{a} R=\sum\left\|F_{\mathrm{o}}|=| F_{\mathrm{c}}\right\| / \sum\left|F_{\mathrm{o}}\right| ; R_{\mathrm{w}}=\left(\sum\left(\left|F_{\mathrm{o}}\right|-\left|F_{\mathrm{c}}\right|\right)^{2} / \sum w\left|F_{\mathrm{o}}\right|^{2}\right)^{1 / 2}, 1 / w$ $=\sigma^{2}\left(F_{0}\right)+0.0000 F_{0}^{2}$

solution is reduced to dryness. The brownish-red solid is dissolved in $30 \mathrm{~mL}$ of $n$-hexane and the solution stored at $-30^{\circ} \mathrm{C}$ to afford $2.18 \mathrm{~g}$ of crystalline material, which is subsequently chromatographed on basic alumina. Elution with light petroleum ether removes a green band which is collected and reduced to dryness to give $108 \mathrm{mg}(2.2 \%)$ of black crystals, decomposition above ca. $150^{\circ} \mathrm{C} .{ }^{1} \mathrm{H} \mathrm{NMR}\left(\mathrm{CDCl}_{3}\right): \delta 0.45\left(\mathrm{~s}, 6 \mathrm{H}, \mathrm{SiMe}_{2}\right), 0.56(\mathrm{~s}, 6 \mathrm{H}$, $\mathrm{SiMe}_{2}$ ), 4.86 (s, $2 \mathrm{H}, \mathrm{H}(5), \mathrm{H}(11)$ ), 5.11 (s, $4 \mathrm{H}, \mathrm{H}(4), \mathrm{H}(6), \mathrm{H}(10)$, $\mathrm{H}(12)) .{ }^{13} \mathrm{C}\left\{{ }^{1} \mathrm{H}\right\} \mathrm{NMR}\left(\mathrm{C}_{6} \mathrm{D}_{6}\right): \delta-3.6(\mathrm{Me}), 3.6(\mathrm{Me}), 82.3(\mathrm{C}(5)$, $\mathrm{C}(11)), 92.2(\mathrm{C}(1), \mathrm{C}(3), \mathrm{C}(7), \mathrm{C}(9)), 94.1(\mathrm{C}(4), \mathrm{C}(6), \mathrm{C}(10), \mathrm{C}(12))$, $220.2(\mathrm{CO}) .{ }^{29} \mathrm{Si} \mathrm{NMR}\left(\mathrm{C}_{6} \mathrm{D}_{6}\right): \delta-13.6$. IR $\left(\mathrm{cm}^{-1}\right): 3110(\mathrm{vw})$, 3095 (w), 2954 (vw), 2004 (s), 1943 (s), $1918(\mathrm{~m}), 1766(\mathrm{~s}), 844(\mathrm{~m})$, $816(\mathrm{~m}), 620(\mathrm{~m})$. MS: $m / e(\%) 466\left(\mathrm{M}^{+}, 8\right), 438\left(\left[\mathbf{M}^{+}-\mathrm{CO}\right]\right.$, 4), $410\left(\left[\mathrm{M}^{+}-2 \mathrm{CO}\right], 34\right), 382\left(\left[\mathrm{M}^{+}-3 \mathrm{CO}\right], 3\right), 354\left(\left[\mathrm{M}^{+}-4 \mathrm{CO}\right]\right.$, $100), 298\left(\left[\mathrm{M}^{+}-4 \mathrm{CO}-\mathrm{Fe}\right], 9\right), 177\left([\mathrm{M}-4 \mathrm{CO}]^{2+}, 16\right)$. Anal. Calcd for $\mathrm{C}_{18} \mathrm{H}_{18} \mathrm{Fe}_{2} \mathrm{O}_{4} \mathrm{Si}_{2}$ (466.2): $\mathrm{C}, 46.37 ; \mathrm{H}, 3.89$. Found: $\mathrm{C}, 46.74$; $\mathrm{H}, 4.11$.

X-ray Structure Determination of 5 and 6 . The structure of these compounds was determined from single-crystal X-ray diffraction data, which were collected using a Syntex $\mathrm{P} 2{ }_{1}$ fourcircle diffractometer for compound 5 and an Enraf-Nonius CAD4 four-circle diffractometer for compound 6. Crystal data and details concerning the intensity data collection and structure refinement are given in Tables VII and VIII. For compound 5 the structure was solved by direct methods (SHELXTL PLUS program package). ${ }^{19}$ The $\mathrm{H}$ atoms were included in the calculation using a riding model with fixed isotropic $U$ values. The final least-squares refinements converged at the values given in Table VII. The last difference Fourier synthesis showed no significant maxima; the highest peak in the last difference Fourier map had a magnitude of $0.44 \mathrm{e} \AA^{-3}$. As can be seen from Table VII, $\alpha$ and $\beta$ are very close to $90^{\circ}$; however, structure refinement assuming the monoclinic space group $P 2_{1} / c$ with $\alpha=\beta=90^{\circ}$ resulted in a final $R$ factor of 0.115 . For compound 6 the structure was solved using the Patterson

(19) Siemens Analytical X-Ray Instruments, Inc., 1989.
Table VIII. Crystal Data, Intensity Measurement, and Refinement Parameters for 6

empirical formula: $\mathrm{C}_{18} \mathrm{H}_{18} \mathrm{Co}_{2} \mathrm{O}_{4} \mathrm{Si}_{2}$

$\mathrm{fw}=472.4$

cryst systm: monoclinic $(Z=4)$

space group: $P 2_{1} / n$

$a=10.496(2) \AA, b=13.380(2) \AA, c=14.537(6) \AA$

$\alpha=90.0^{\circ}, \beta=92.96(3)^{\circ}, \gamma=90.0^{\circ}$

$V=2038.8(3) \AA^{3}$

$d_{\text {calcd }}=1.54 \mathrm{~g} \mathrm{~cm}^{-3}$

$\mu($ Mo $\mathrm{K} \alpha)=1.76 \mathrm{~mm}^{-1}$

$F(000)=960$

radiatn: Mo $\mathrm{K} \alpha$ (graphite monochromator, $\lambda=0.71069 \AA$ )

scan mode: $\omega$-scan

scan range $(2 \theta): 3-45^{\circ}$

scan speed: variable; $1.4-6.8^{\circ} / \mathrm{min}$ in $\omega$

bkgd measurement: stationary crystal and stationary counter at

beginning and end of scan, each for $25.0 \%$ of total scan time temp $=293 \mathrm{~K}$

check reflctns: 3 reflctns every 100 reflctns

index ranges: $-11 \leq h \leq 11,0<k<14,0<l<16$

abs corrn: semiempirical

$\min / \max$ transm: $0.85 / 1.00$

no. of reflctns collcd: 2951

no. of ind reflctns: $2838\left(R_{\text {int }}=1.3 \%\right)$

no. of obsd reflctns: $2269\left(F_{0}>3.0 \sigma\left(F_{0}\right)\right)$

no. of variables: 307

$R=0.032^{a}$

$R_{\mathrm{w}}=0.037^{a}$

${ }^{a} R=\sum\left\|F_{\mathrm{o}}|-| F_{\mathrm{c}}\right\| / \sum\left|F_{\mathrm{o}}\right| ; R_{\mathrm{w}}=\left(\sum\left(\left|F_{\mathrm{o}}\right|-\left|F_{\mathrm{c}}\right|\right)^{2} / \sum w\left|F_{\mathrm{o}}\right|^{2}\right)^{1 / 2}, 1 / w$ $=\sigma^{2}\left(F_{0}\right)+0.0005 F_{0}^{2}$.

method (SHELX 76 program package). ${ }^{20} \mathrm{H}$ atoms were included in idealized positions with group isotropic displacement coefficients. The final least-squares refinements converged at the values given in Table VIII. The last difference Fourier synthesis showed no significant maxima; the highest peak in the last difference Fourier map had a magnitude of 0.27 e $\AA^{-3}$. For both structure determinations atomic scattering factors were taken from standard sources. ${ }^{21}$

Acknowledgment. This work was financially supported by the Deutsche Forschungsgemeinschaft and the Fonds der Chemischen Industrie. U.S. thanks the Studienstiftung des deutschen Volkes for a dissertation stipend.

Registry No. trans-1, 138784-73-3; cis-1, 75794-34-2; 2, 134153-32-5; 3, 138784-74-4; trans-4, 138784-75-5; cis-4, 13887491-6; 5, 138784-77-7; cis-6, 138784-78-8; trans-6, 138874-92-7; 7, 138784-76-6; chlorocyclopentadienyldimethylsilane, 13688-59-0; methoxytrimethylsilane, 1825-61-2; trimethyltin chloride, 106645-1; chloro(pentamethylcyclopentadienyl)ruthenium(II), 121334-82-5; octacarbonyldicobalt, 10210-68-1; pentacarbonyliron, 13463-40-6.

Supplementary Material Available: Complete lists of bond lengths and angles, anisotropic thermal parameters, coordinates of hydrogen atoms, and atomic coordinates for compound 5 and listings of bond angles, anisotropic thermal parameters, hydrogen atom coordinates, and hydrogen bond lengths and angles for compound 6 (15 pages); listings of calculated and observed structure factors (58 pages). Ordering information is given on any current masthead page.

(20) Sheldrick, G. M. SHELX 76 Crystallographic Calculation Program; University of Cambridge: Cambridge, U.K., 1976.

(21) International Tables for X-ray Crystallography; Kynoch Press: Birmingham, England, 1974; Vol. IV. 